\title{
Limited genetic differentiation among wild Oryctolagus cuniculus L. (rabbit) populations in arid eastern Australia
}

\author{
SUSAN J. FULLER* ${ }^{*}$ PETER B. MATHER \& JOHN C. WILSON \\ School of Life Science and Centre for Biological Population Management, Queensland University of Technology, \\ GPO Box 2434, Brisbane, 4001, Australia
}

\begin{abstract}
A systems approach is necessary for effective control of feral rabbit (Oryctolagus cuniculus L.) populations in the arid environments of Australia. Localized control procedures may result in local extinctions, but the persistence of the overall population will depend on the probability of recolonization, and hence, the degree of isolation of each local population unit. Genetic markers obtained using allozyme electrophoresis, temperature gradient gel electrophoresis (TGGE) and heteroduplex analysis (HA) were used to characterize the degree of structuring and extent of gene flow among rabbit populations in arid Queensland, Australia. Allozyme allele frequency data showed that there was no significant differentiation among sites (average $F_{\mathrm{ST}}=0.005$ ) and no isolation-by-distance or environmental discontinuity effects. TGGE/HA results also revealed no significant differentiation in mitochondrial DNA Control Region haplotype frequencies among sites and low interpopulation nucleotide divergence estimates $\left(N_{\mathrm{ST}}=0.013\right)$. Therefore, rabbit populations exhibited a high degree of gene flow over large geographical areas $\left(1600 \mathrm{~km}^{2}\right)$ and were essentially a single panmictic unit. Unpredictable environmental conditions together with the spatial configuration of habitats which possess different probabilities of extinction may have resulted in repeated local extinctions followed by recolonization and homogenizing gene flow. These data suggest that current rabbit control strategies based on individual warren management may not achieve effective control in arid Queensland.
\end{abstract}

Keywords: allozymes, control region, genetic differentiation, heteroduplex analysis, mtDNA, temperature gradient gel electrophoresis.

\section{Introduction}

Between 13 and 24 wild rabbits (Oryctolagus cuniculus L.) of English origin were released in Victoria, Australia in 1859 and within 60 years, rabbits had colonized most of temperate and sub-tropical Australia (Stodart \& Parer, 1988). This rapid range expansion can be attributed to efficient reproductive biology, good competitive ability and the absence of significant predators and parasites in Australia (Rural Lands Protection Board, 1987). Pasture damage by rabbits, in conjunction with the loss of grazing through competition for feed is estimated to cost Australia \$A60-90 million annually (Wilson et al., 1992).

Effective population control will depend on the integrity of the local population unit and the degree

\footnotetext{
*Correspondence.
}

of isolation of each unit. It is therefore necessary to determine the appropriate geographical scale for management, i.e. define the boundaries of a demographically independent population or 'management unit' (Moritz, 1994). Despite the high dispersal potential of the rabbit, the warren, a discrete and easily identifiable unit, has been conveniently adopted as the appropriate level at which control procedures should be applied. This level of scale may be appropriate in certain areas of New South Wales. Daly (1979) showed that although the social organization of rabbit populations in areas of New South Wales was hierarchical, it did not result in significant genetic microdifferentiation as paternity was shared and infidelities occurred between social groups. Nonetheless, Richardson (1980) found significant heterogeneity in allele frequencies among warren groups in New South Wales over distances as little as $1 \mathrm{~km}$ suggesting that in certain regions of 
Australia control may be effective when applied on a relatively small scale.

Because social organization may differ between localities, it is not possible to generalize the use of warren management techniques (e.g. baiting, fumigation or destruction) to all areas. Furthermore, in arid Australia, control via myxomatosis generally results in only localized control around the inoculation site (warren) as the spread of the virus is limited by the lack of reliable transmission vectors (Rural Lands Protection Board, 1987).

Previous studies in New South Wales provided a preliminary framework on which to base the design of the present study. The dissected dune systems of arid Queensland consist of large parallel sand ridges (1-5 km in length) separated by wide $(0.5-5 \mathrm{~km}$ in width) claypans (DPI Land Use Report, 1974). In these systems, higher levels of gene flow were expected among local rabbit populations, owing to unpredictable climate and fluctuating rabbit population sizes (Cooke, 1981). Moreover, intergroup interactions are also expected to be more fluid because of the presence of communal grazing areas (claypans) distinct from the breeding areas (sand hills) that support high density rabbit populations. Rowley (1968) and Parer \& Parker (1987) have shown that depopulated warrens can rapidly be recolonized by adjacent populations. The present study was designed to investigate differences among rabbit populations on sand hills (with each sand hill consisting of multiple warrens) separated by variable distances and physical geographical barriers in arid Queensland.

In rabbits, up to five polymorphic enzyme systems have been used to detect variation in the underlying genes (Daly, 1979; Richardson, 1980; Richardson et al., 1980, 1986; Webb, 1988). Mitochondrial (mt) DNA has been recognized as a sensitive indicator of population subdivision (Wilson et al., 1985). In particular, the Control Region has a high rate of evolution compared to the rest of the mitochondrial genome (Aquadro \& Greenberg, 1983) and permits the greatest opportunity for the detection of genetic differentiation among populations. In the present study, genetic markers were obtained using allozyme electrophoresis, and temperature gradient gel electrophoresis (TGGE) and heteroduplex analysis (HA) of an mtDNA Control Region fragment. TGGE and HA techniques are capable of detecting allelic variation in DNA sequences (see Lessa \& Applebaum, 1993) and TGGE can theoretically detect single base changes in genomic DNA (Myers et al., 1988; Riesner et al., 1989; Wartell et al., 1990). The fraction of base mismatches resolved can be improved by using heteroduplex formation in combination with TGGE (Myers et al., 1985; Myers \& Maniatis, 1986). Recently, HA has been applied to haploid loci, where only one type of target sequence is present per sample (e.g. mtDNA; Campbell et al., 1995).

The specific objectives of the present study were (i) to examine genetic differentiation among rabbit populations separated by varying distances $(7.5-50 \mathrm{~km}$ apart) and thus to determine the relative importance of gene flow and the degree of isolation among local populations, and (ii) to identify potential habitat or geographical barriers to gene flow.

\section{Materials and methods}

\section{Sample collection}

Approximately 100 adult rabbits were collected from each of nine sites at Bulloo Downs, south-west Queensland (Fig. 1). These sites were selected at varying degrees of geographical isolation, equidistant either side and across the Bulloo River, to allow the examination of distance and possible barrier effects on gene flow. Rabbits were shot and a small section of liver was collected from each individual and stored in a Cryoware vial (Nalgene Co.) under liquid nitrogen. On return to the laboratory, samples were immediately transferred to a $-80^{\circ} \mathrm{C}$ freezer.

\section{Allozyme electrophoresis}

Part of each liver sample was homogenized in buffer (according to Richardson et al., 1986) and then centrifuged at $8500 \mathrm{~g}$ for $15 \mathrm{~min}$ at $4^{\circ} \mathrm{C}$. The supernatant was removed and used immediately for electrophoresis. Protein electrophoresis was performed on Titan III Zip Zone cellulose acetate plates (Helena Laboratories, TX, U.S.A.), following the running and staining conditions given by Richardson et al. (1986). Where multiple loci were present for an individual enzyme, the most anodal was designated as 1 . Alleles at polymorphic loci were assigned numerical designations as anodal (1) to cathodal (3). In a previous study on wild rabbits, Richardson et al. (1980) screened 26 enzyme loci. An additional 19 enzymes were screened in the present study and two additional polymorphic loci (aldehyde dehydrogenase and aldehyde oxidase) were identified. In total, six polymorphic loci were assayed in this study (6Pgd-1, Est-1, Ada-1, Ca-1, Aldh-1 and Aox-2); however, $\mathrm{Ca}-1$ could not be scored consistently and was later excluded from the analysis. 


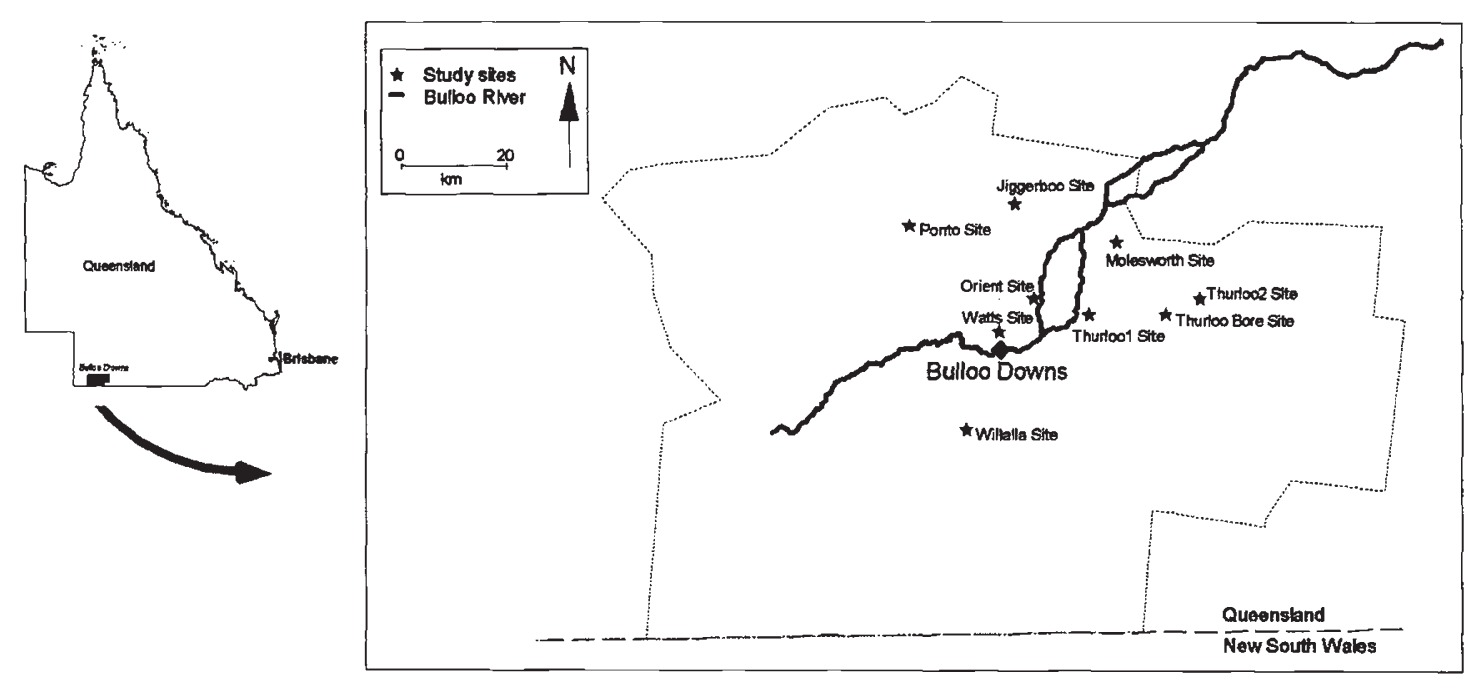

Fig. 1 Location of rabbit study sites at Bulloo Downs, south-west Queensland.

BIOsys-1 (Swofford \& Selander, 1989) was used to calculate $\chi^{2}$ contingency tests for homogeneity, Wright's (1951) F-statistics and Rogers's genetic distance estimates (Rogers, 1972) from allozyme data.

\section{MtDNA Control Region analyses}

Total DNA was extracted from $\approx 100 \mathrm{mg}$ of liver tissue from 10 individuals per site, by grinding to a fine powder in liquid nitrogen and then incubating at $55^{\circ} \mathrm{C}$ for $3 \mathrm{~h}$ in an extraction buffer consisting of $100 \mathrm{~mm}$ Tris(hydroxymethyl)aminomethane (Tris), $20 \mathrm{~mm}$ EDTA, $100 \mathrm{~mm}$ sodium chloride, 10 per cent sodium dodecyl sulphate, $2 \mathrm{M}$ dithiothreitol and $10 \mathrm{mg} / \mathrm{mL}$ proteinase $\mathrm{K}$. The isolation procedure consisted of a phenol extraction, followed by a series of phenol:chloroform (1:1) extractions, ending in a chloroform extraction. All centrifugation was performed at $12000 \mathrm{~g}$. DNA was precipitated in $3 \mathrm{M}$ sodium acetate $\left(\mathrm{pH} \mathrm{5.2)}\right.$ and 100 per cent $\left(-20^{\circ} \mathrm{C}\right)$ ethanol at $-80^{\circ} \mathrm{C}$, and then redissolved in $50 \mu \mathrm{L}$ of Tris-EDTA buffer, $\mathrm{pH}$ 7.5.

A $523 \mathrm{bp}$ region of DNA flanking the tRNAproline gene in the mtDNA Control Region was amplified using polymerase chain reaction (PCR) (Saiki et al., 1988). This portion was amplified using a 22 bp primer created by M. S. Elphinstone (Southern Cross University) of sequence $5^{\prime}$-CTCCACCATCAGCACCCAAAGC-3' in thetRNA-prolinegeneand a $20 \mathrm{bp}$ internal primer of sequence 5'-CCTGAAGTAGGAACCAGATG-3' created by Meyer et al. (1990), located in the central conserved domain of the mammalian Control Region. The equivalent fragment in other mammalian species has been found to be hypervariable (Saccone et al., 1991).

Individual PCR reactions were performed in a $25 \mu \mathrm{L}$ volume containing deoxynucleoside triphosphate (Promega) at a final concentration of $100 \mu \mathrm{M}$, Boehringer-Mannheim Taq $10 \times$ buffer (containing magnesium chloride at a final concentration of $1.5 \mathrm{~mm}), 120 \mathrm{~nm}$ of primer $1,120 \mathrm{~nm}$ of primer 2 and $0.5 \mathrm{U}$ of Taq polymerase (Boehringer-Mannheim). The reactions were mixed and overlaid with $25 \mu \mathrm{L}$ of light paraffin oil. Template DNA (100 ng) was added to the mixture through the oil. Temperature cycling was carried out in a programmable 'Minicycler' thermal controller (MJ Research Inc.) with the following cycle program: (1) $94^{\circ} \mathrm{C}$ for $30 \mathrm{~s}$, (2) $50^{\circ} \mathrm{C}$ for $10 \mathrm{~s}$, (3) $72^{\circ} \mathrm{C}$ for $1 \mathrm{~min},(4) 94^{\circ} \mathrm{C}$ for $10 \mathrm{~s}$, (5) $50^{\circ} \mathrm{C}$ for $30 \mathrm{~s},(6)$ cycle to step 3,34 more times, (7) $72^{\circ} \mathrm{C}$ for $5 \mathrm{~min}$ and (8) $4^{\circ} \mathrm{C}$ for overnight storage. A negative control containing no genomic DNA was included in every PCR experiment. Amplification products and a DNA size marker $(\phi \times 174$ - HaeIII) were resolved in a 1 per cent Tris-borate-EDTA agarose gel, $\mathrm{pH} 8$ at $100 \mathrm{~V}$. The resulting fragment was visualized by ethidium bromide fluorescence on a UV light transilluminator.

PCR products were stored at $-20^{\circ} \mathrm{C}$ until required for heteroduplex analysis by TGGE. The protocol for heteroduplex formation is given in the TGGE Handbook (1993). Each PCR product ( $\approx 10 \mathrm{ng}$ ) was heteroduplexed with a single reference rabbit PCR product.

The DIAGEN horizontal TGGE system was used for heteroduplex analysis of rabbit DNA samples (TGGE Handbook, 1993). Optimal temperature 
gradient conditions were determined by electrophoresis $(300 \mathrm{~V}, 20-30 \mathrm{~mA}, 1.5 \mathrm{~h})$ of the doublestranded product through a 5 per cent polyacrylamide gel, over a perpendicular gradient of temperature from 20 to $60^{\circ} \mathrm{C}$. Subsequent electrophoretic runs were of $4 \mathrm{~h}$ duration, using a parallel temperature gradient of 11 to $46^{\circ} \mathrm{C}$. Internal standards (i.e. known sequence variants of differential mobility) were included on every gel. The DNA was visualized using the silver staining procedure given in the TGGE Handbook (1993).

Approximately $100 \mathrm{ng}$ purified DNA fragment (QIAquick PCR Purification Preps, QIAGEN Inc.) and 3.2 pmol primer were sequenced using $A B I$ (Applied Biosystems) automated DNA sequencing. Each DNA fragment was sequenced (in the majority of cases, twice) from both the $3^{\prime}$ and $5^{\prime}$ ends. Sequences were aligned by eye using a sequence editor program (ESEE, Version 1.09D). Replicate sequencing (for each haplotype, $n=5$ ) was performed, to confirm that individuals of identical haplotype possessed the same sequence.

$\chi^{2}$ contingency tests were used to determine the significance of haplotype frequencies among sites.
Evolutionary distance among haplotypes was calculated using the Jukes \& Cantor (1969) correction and intra- and interpopulation nucleotide divergences were calculated using the distance-based analysis of Lynch \& Crease (1990). $N_{\mathrm{ST}}$ was calculated according to Lynch \& Crease (1990) and $\mathrm{Nm}$ values for haploid data were determined according to Hudson et al. (1992).

\section{Results}

\section{Assessment of genetic differentiation: allozyme markers}

Four out of five enzyme loci were highly polymorphic (Table 1). There were no significant differences $(P>0.05)$ in allele frequencies across all sites, for each locus, indicating that alleles occurred at homogeneous frequencies. Sites were grouped on the basis of geographical feature (i.e. north and south of the Bulloo River) and for all loci, there were no significant differences $(P>0.05)$ in frequencies, suggesting that the Bulloo River was not a significant barrier to interchange.

Table 1 Allele frequencies for the nine rabbit populations at Bulloo Downs

\begin{tabular}{lccccccccc}
\hline Locus & JigBr & MW & Orient & Ponto & ThuBr & Thur1 & Thur2 & Watts & Willa \\
\hline 6 Pgd-1 & & & & & & & & & \\
$n:$ & 100 & 95 & 102 & 100 & 103 & 96 & 106 & 98 & 82 \\
1 & 0.95 & 0.98 & 0.95 & 0.95 & 0.96 & 0.95 & 0.95 & 0.95 & 0.98 \\
2 & 0.05 & 0.02 & 0.05 & 0.05 & 0.04 & 0.05 & 0.05 & 0.05 & 0.02 \\
Ada-1 & & & & & & & & & \\
$n:$ & 99 & 77 & 84 & 100 & 103 & 71 & 86 & 93 & 80 \\
1 & 0.22 & 0.24 & 0.33 & 0.25 & 0.33 & 0.23 & 0.24 & 0.27 & 0.27 \\
2 & 0.70 & 0.68 & 0.62 & 0.66 & 0.59 & 0.66 & 0.65 & 0.60 & 0.68 \\
3 & 0.08 & 0.08 & 0.05 & 0.09 & 0.08 & 0.11 & 0.11 & 0.13 & 0.05 \\
Est-1 & & & & & & & & & \\
$n:$ & 100 & 91 & 102 & 100 & 102 & 96 & 105 & 97 & 82 \\
1 & 0.52 & 0.47 & 0.44 & 0.44 & 0.42 & 0.43 & 0.44 & 0.45 & 0.50 \\
2 & 0.48 & 0.53 & 0.56 & 0.56 & 0.58 & 0.57 & 0.56 & 0.55 & 0.50 \\
Aldh-1 & & & & & & & & & \\
$n:$ & 100 & 94 & 101 & 100 & 102 & 96 & 106 & 98 & 82 \\
1 & 0.61 & 0.65 & 0.56 & 0.60 & 0.57 & 0.59 & 0.58 & 0.63 & 0.57 \\
2 & 0.24 & 0.20 & 0.27 & 0.25 & 0.25 & 0.25 & 0.29 & 0.19 & 0.23 \\
3 & 0.15 & 0.15 & 0.17 & 0.15 & 0.18 & 0.16 & 0.13 & 0.18 & 0.20 \\
Aox-2 & & & & & & & & & \\
$n:$ & 100 & 92 & 101 & 100 & 102 & 95 & 105 & 96 & 81 \\
1 & 0.80 & 0.83 & 0.80 & 0.81 & 0.74 & 0.75 & 0.75 & 0.78 & 0.75 \\
2 & 0.20 & 0.17 & 0.20 & 0.19 & 0.26 & 0.25 & 0.25 & 0.22 & 0.25 \\
\hline
\end{tabular}

JigBr, Jiggerboo Bore; MW, Molesworth; ThuBr, Thurloo Bore; Thur1, Thurloo 1; Thur2, Thurloo 2; Willa, Willalla.

$n$, sample size. 


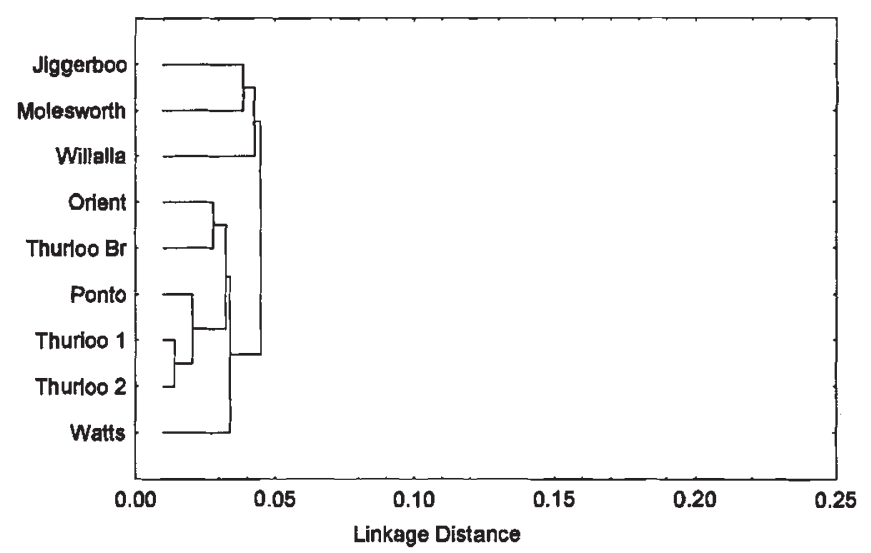

Fig. 2 Cluster analysis of rabbit populations using unweighted pair-group average method based on Rogers's genetic distance coefficients.

In the majority of cases ( 92.5 per cent), loci did not deviate from Hardy-Weinberg equilibrium, with significant deviations $(P<0.05)$ detected in only six out of 45 cases. Significant deviations were not confined to a single locus and were considered to be random.

Rogers's genetic distance estimates based on pairwise comparisons of the nine sites, for the five loci, ranged from 0.014 to 0.066 indicating that populations were very similar to one another. There was no pattern in the clustering of sites relative to position either side of the Bulloo River or with distance among sites (Fig. 2). The linkage distances were so low that any groupings in the cluster could be considered to be random associations.

The absence of any isolation-by-distance effect is supported by a poor correlation $(r=-0.057, n=36$, $P>0.05)$ between genetic distance and geographical distance separating localities.

There was very low ( 0.5 per cent) genetic differentiation (mean $F_{\mathrm{ST}}=0.005$, range 0.004-0.007) among subpopulations (consistent over all loci), and consequently, a level of gene flow $(\mathrm{Nm}=52)$ that was sufficient to prevent substantial differentiation because of random genetic drift.

\section{Assessment of genetic differentiation: $m t D N A$ markers}

Haplotype frequencies are displayed in Table 2 . There were no significant differences in haplotype frequencies among all sites $\left(\chi_{16}^{2}=20.03, P=0.2189\right)$ despite the inflation of the $\chi^{2}$-value owing to low expected values. There was also no significant difference in haplotype frequencies among sites north and south of the Bulloo River $\left(\chi_{2}^{2}=5.18, P=0.075\right)$.

The absolute and percentage sequence divergence among the three haplotypes ranged from 0.8 to 2.2 per cent (Table 3). Replicate haplotypes showed identical sequences. Haplotype frequencies were weighted according to nucleotide divergence among haplotypes, and were used in the calculation of intra- and interpopulation nucleotide divergence. Average intrapopulation diversity was 0.8 per cent, whereas average interpopulation diversity was 0.01 per cent, indicating little or no genetic divergence within and among populations. There were no major associations of sites in the cluster of pairwise interpopulation nucleotide divergence estimates and differentiation among sites was less than that observed in allozyme comparisons.

Table 3 Matrix of pairwise percentage sequence divergence estimates (below diagonal) and absolute distance estimates (above diagonal) for the three rabbit mtDNA haplotypes

\begin{tabular}{lccr}
\hline Haplotype & A & B & C \\
\hline A & - & 4 & 7 \\
B & 0.78 & - & 11 \\
C & 1.38 & 2.18 & - \\
\hline
\end{tabular}

Table 2 MtDNA haplotype frequencies for the nine rabbit populations at Bulloo Downs

\begin{tabular}{lccccccccc} 
Locus & JigBr & MW & Orient & Ponto & ThuBr & Thur1 & Thur2 & Watts & Willa \\
\hline mtDNA & & & & & & & & & \\
$n:$ & 10 & 10 & 11 & 12 & 12 & 11 & 11 & 13 & 12 \\
A & 0.30 & 0.80 & 0.73 & 0.25 & 0.50 & 0.54 & 0.46 & 0.54 & 0.67 \\
B & 0.40 & 0.10 & 0.09 & 0.33 & 0.17 & 0.00 & 0.09 & 0.31 & 0.17 \\
C & 0.30 & 0.10 & 0.18 & 0.42 & 0.33 & 0.46 & 0.46 & 0.15 & 0.16 \\
\hline
\end{tabular}

JigBr, Jiggerboo Bore; MW, Molesworth; ThuBr, Thurloo Bore; Thur1, Thurloo 1; Thur2, Thurloo 2; Willa, Willalla.

$n$, sample size. 
The correlation between interpopulation nucleotide divergence and geographical distance was extremely poor $(r=-0.035, n=36, P>0.05)$ indicating no isolation-by-distance effect.

The $N_{\mathrm{ST}}$ estimate indicated that there was little or no ( 1 per cent) genetic differentiation among subpopulations and an $\mathrm{Nm}$ value of 38 indicated a high level of gene flow. Gene flow was therefore the major homogenizing force preventing differentiation because of random genetic drift.

\section{Discussion}

In the present study limited genetic microdifferentiation in rabbit subpopulations was shown by the data conforming to Hardy-Weinberg equilibrium and both allozyme and mtDNA analysis indicating little or no genetic divergence and high gene flow within and among populations. There were no trends in divergence that could be attributed to habitat barrier effects or distance effects. The Bulloo River is an ephemeral string of waterholes which only becomes a continuous flow when the channels flood during summer. Therefore, any potential barrier effects to gene flow during summer could be negated by migration in the nonflow periods. These results suggest that in arid Queensland, rabbit populations are effectively panmictic over $1600 \mathrm{~km}^{2}$. As there was no isolation-by-distance effect and therefore no local clustering of similar alleles or haplotypes, migrants can be assumed to be drawn at random from a total population comprised of geographically dispersed (sand hill) subpopulations.

The high rate of gene flow observed in this study is contrary to previous investigations in southern Australia that have indicated the minimum distance necessary for significant differentiation to develop among rabbit populations to be $20-30 \mathrm{~km}$ based on morphological (skull) divergence (Taylor et al., 1977 ) and $1 \mathrm{~km}$ based on biochemical (allozyme) divergence (Richardson, 1980). At distances comparable to those used in this study, Richardson et al. (1980) concluded from allozyme electrophoretic data that southern populations were significantly differentiated and that effective migration was very limited. The different genetic patterns found in the previous and present studies can be attributed to the unique spatial configuration of habitats and resource pressures associated with the arid environment of south-west Queensland resulting in a high level of gene flow between local populations.

Several models have been proposed to explain population and genetic structure in small mammal populations that emphasize the importance of social structure. The propensity for small mammals, particularly rodents, to form small breeding groups or demes as a consequence of social organization was recognized by Anderson (1970) and Selander (1970). Anderson (1970) concluded that gene flow was so restricted that genetic homogeneity was not maintained among different populations of the same species. Similarly, significant genetic heterogeneity in Mus populations was detected over an area as small as a single barn, and was considered to be the result of social structuring (Selander, 1970). This model of demic organization has also been applied to Peromyscus (Rasmussen, 1970).

Several ecological studies (Myers \& Poole, 1959; Cowan, 1987) have reported a high degree of social organization within rabbit populations. In contrast, several genetic studies on rabbit populations (Daly, 1979; Webb, 1988) have revealed that social structuring may not be so strict as to lead to genetic structuring. In marmot (Marmota flaviventris) populations a similar genetic structure was reported, with a high rate of gene flow occurring into colonies and a de facto avoidance of inbreeding, reducing the effects of social organization (Schwartz \& Armitage, 1980). Daly (1979) suggested that the demic organization model may overemphasize the importance of small mammal social structure in natural populations and that the extent of genetic structuring will depend on environmental diversity (the presence and spatial configuration of different habitats) and conditions (optimum habitats changing with environmental fluctuations). Similarly, the genetic structure of vole (Microtus californicus) populations (Bowen, 1982) and cottontail rabbit (Sylvilagus floridanus) populations (Scribner \& Chesser, 1993) was not solely the result of social structure, but was also found to be dependent on ecological and demographic parameters. In summary, genetic structure cannot be assumed to be the product of a single factor (e.g. social behaviour), but should be considered to be influenced by a range of factors including the modification of behaviour in response to resource availability.

In the long-term, different social and mating systems may arise as a result of environmental heterogeneity. Cowan \& Garson (1985) reported that when nest sites were clumped (commonly on heavy burrowing substrate), both burrows and mates were limiting resources and social groups formed. However, where nest sites were sparsely distributed (on light sandy soil) and food was a major limiting factor, social organization was more relaxed.

Daly (1979) reported that local habitat heterogeneity will influence population structure and 
dynamics and that gene flow may be increased in two ways; population expansion after a favourable change in the weather pattern and successful dispersal into recently occupied areas after a population crash. In the unpredictable arid dune systems of Queensland, unreliable weather patterns and the highly dissected spatial pattern of habitats which possess different survival properties may lead to large fluctuations in rabbit population size.

Migration as estimated by the island model, does not take into account extreme population fluctuations, where gene flow may result more from recolonization after local extinctions rather than from a regular pattern of dispersal among populations (Slatkin, 1985). In arid south-west Queensland, this scenario may be quite likely because of the catastrophic environment (leading to drastic fluctuations in population size; Cooke, 1981) and continued attempts at localized control, resulting in repeated local extinction and recolonization of depopulated areas (Rowley, 1968; Myers \& Parker, 1975a,b). The combined turnover of many local populations in the study area may result in high gene flow among local populations and, overall, a genetically homogeneous system. Gene flow would also be enhanced by contact among individuals in communal feeding grounds (claypans) between separate breeding areas (sand hills).

Mass emigrations of rabbits over large distances have also been observed when resource (food, water, shelter) shortage develops over a large area, as in a drought year in the Australian arid zone (Myers $e t$ al., 1994). At this point, it cannot be ascertained whether gene flow is the product of widespread dispersal and/or the result of a series of local extinction and recolonization events. In either case, the presence of extensive gene flow over large distances suggests that the demic organization model is inappropriate for rabbit populations and an environmental diversity model similar to that of Daly (1979) is more appropriate for rabbit populations in the arid dune systems of Queensland. Consequently, management strategies for rabbit populations in these environments should be directed towards control at a regional level as individual warren management will have little long-term impact.

\section{Acknowledgements}

The authors would like to acknowledge the assistance of Prof. Peter Baverstock and research staff of the Conservation Genetics Laboratory, Southern Cross University, with the TGGE analyses and the staff of the Lands Protection Unit for advice and field support. Susan Fuller's research was performed with the aid of funding from the Centre for Biological Population Management and a QUT Postgraduate Research Award.

\section{References}

ANDERSON, P. K. 1970. Ecological structure and gene flow in small mammals. Symp. Zool. Soc. Lond., 26, 299-325.

AQUADRO, C. F. AND GREENBERG, B. D. 1983. Human mitochondrial DNA variation and evolution: analysis of nucleotide sequences from seven individuals. Genetics, 103, 287-312.

BOWEN, B. s. 1982. Temporal dynamics of microgeographic structure of genetic variation in Microtus californicus. $J$. Mammal., 63, 625-638.

CAMPBELL, N. J. H., HARRISS, F. C., ELPHINSTONE, M. S. AND BAVERSTOCK, P. R. 1995. Outgroup heteroduplex analysis using temperature gradient gel electrophoresis: high resolution, large scale, screening of DNA variation in the mitochondrial DNA control region. Mol. Ecol., 4, 407-418.

COOKE, B. D. 1981. Food and dynamics of rabbit populations in inland Australia. In: Myers, K. and MacInnes, C. D. (eds) Proceedings of the World Lagomorph Conference, pp. 633-647. University of Guelph, Ont.

COWAN, D. P. 1987. Group living in the European rabbit (Oryctolagus cuniculus): mutual benefit or resource localization? J. Anim. Ecol., 56, 779-795.

COWAN, D. P. AND GARSON, P. J. 1985. Variations in the social structure of rabbit populations: causes and demographic consequences. In: Sibley, R. M. and Smith, R. H. (eds) Behavioural Ecology: Ecological Consequences of Adaptive Behaviour, pp. 537-555. Blackwell Scientific Publications, Oxford.

DALY, J. 1979. The Ecological Genetics of the European Wild Rabbit (Oryctolagus Cuniculus (L.)) in Australia. Ph.D. Thesis, Australian National University.

DPI LAND USE REPORT. 1974. Western Arid Region Land Use Study. Part 1. QDPI, Queensland.

HUDSON, R. R., SLATKIN, M. AND MADDISON, W. P. 1992. Estimation of levels of gene flow from DNA sequence data. Genetics, 132, 583-589.

JUKES, T. H. AND CANTOR, C. R. 1969. Evolution of protein molecules. In: Munro, H. N. (ed.) Mammalian Protein Metabolism, pp. 21-123. Academic Press, New York.

LESSA, E. P. AND APPlebAuM, G. 1993. Screening techniques for detecting allelic variation in DNA sequences. Mol. Ecol., 2, 119-129.

LYNCH, M. AND CREASE, T. J. 1990. The analysis of population survey data on DNA sequence variation. Mol. Biol. Evol., 7, 377-394.

MEYER, A., KOCHER, T. D., BASASIBWAKI, P. AND WILSON, A. C. 1990. Monophyletic origin of Victoria cichlid fish suggested by mitochondrial DNA sequences. Nature, 347, 550-553.

MORITZ, C. 1994. Applications of mitochondrial DNA 
analysis in conservation: a critical review. Mol. Ecol., 3, 401-411.

MYERS, K. AND PARKER, B. s. 1975a. A study of the biology of the wild rabbit in climatically different regions in eastern Australia. VI. Changes in numbers and distribution related to climate and land systems in semiarid north-western New South Wales. Aust. Wildl. Res., 2, 11-32.

MYERS, K. AND PARKER, B. S. 1975b. Effect of severe drought on rabbit numbers and distribution in a refuge area in semi-arid north-western New South Wales. Aust. Wildl. Res., 2, 103-120.

MYERS, K. AND POOLE, W. E. 1959. A study of the biology of the wild rabbit Oryctolagus cuniculus (L.) in confined populations. I. The effects of density on home range and the formation of breeding groups. CSIRO Wildl. Res., 4, 14-26.

MYERS, K., PARER, I., WOOD, D. AND COOKE, B. D. 1994. The rabbit in Australia. In: Thompson, H. V. and King, C. (eds) The European Rabbit, pp. 108-157. Oxford University Press, Oxford.

MYERS, R. M. AND MANIATIS, T. 1986. Recent advances in the development of methods for detecting single-base substitutions associated with human genetic diseases. Cold Spring Harb. Symp. Quant. Biol., 51, 275-284.

MYERS, R. M., LUMELSKY, N., LERMAN, L. S. AND MANIATIS, T. 1985. Detection of single base substitutions in total genomic DNA. Nature, 313, 495-498.

MYERS, R. M., SHEFFIELD, v. C. AND COX, D. R. 1988. Detection of single base changes in DNA: ribonuclease cleavage and denaturing gradient gel electrophoresis. In: Davies, K. (ed.) Genome Analysis: a Practical Approach, pp. 95-139. IRL Press, Oxford.

PARER, I. AND PARKER, B. S. 1987. Recolonisation by rabbits (Oryctolagus cuniculus) after warren destruction in western New South Wales. Aust. Rangel. J., 8, $150-152$.

RASMUSSEN, D. I. 1970. Biochemical polymorphisms and genetic structure in populations of Peromyscus. Symp. Zool. Soc. Lond., 26, 335-349.

RICHARDSON, B. J. 1980. Ecological genetics of the wild rabbit in Australia. III. Comparison of the microgeographical distribution of alleles in two different environments. Aust. J. Biol. Sci., 33, 385-391.

RICHARDSON, B. J., BAVERSTOCK, P. R. AND ADAMS, M. 1986. Allozyme Electrophoresis: a Handbook for Animal Systematics and Population Studies. Academic Press, Sydney.

RICHARDSON, B. J., ROGERS, P. M. AND HEWITT, G. M. 1980. Ecological genetics of the wild rabbit in Australia. II. Protein variation in British, French and Australian rabbits and the geographical distribution of the variation in Australia. Aust. J. Biol. Sci., 33, 371-383.

RIESNER, D., STEGER, G., ZIMMAT, R., OWENS, R. A., WAGENHOFER, M., VOLLBACH, S. AND HENCO, K. 1989. Temperature-gradient gel electrophoresis of nucleic acids: analysis of conformational transitions, sequence varia- tions, and protein-nucleic acid interactions. Electrophoresis, 10, 377-389.

ROGERS, J. s. 1972. Measures of genetic similarity and distance. Stud. Gen., 7, 144-153.

ROWLEY, I. 1968. Studies on the resurgence of rabbit populations after poisoning. CSIRO Wildl. Res., 13, 59-69.

RURAL LANDS PROTECTION BOARD 1987. Rabbits and Their Control in Queensland. Queensland Government, Australia.

SACCONE, C., PESOle, G. AND SBISA, E. 1991. The main regulatory region of mammalian mitochondrial DNA: structure-function model and evolutionary pattern. $J$. Mol. Evol., 33, 83-91.

SAIKI, R. K., GELFAND, D. H., STOFFEL, S., SCHARF, S. J., HIGUCHI, R., HORN, G. T. ET AL. 1988. Primer-directed enzymic amplification of DNA with a thermostable DNA polymerase. Science, 239, 487-491.

SCHWARTZ, O. A. AND ARMITAGE, K. B. 1980. Genetic variation in social mammals: the marmot model. Science, 207, 665-667.

SCRIBNER, K. T. AND CHESSER, R. K. 1993. Environmental and demographic correlates of spatial and seasonal genetic structure in the eastern cottontail (Sylvilagus floridanus). J. Mammal., 74, 1026-1044.

SELANDER, R. K. 1970. Biochemical polymorphisms in populations of the house mouse and old-field mouse. Symp. Zool. Soc. Lond., 26, 73-91.

SLATKIN, M. 1985. Gene flow in natural populations. Ann. Rev. Ecol. Syst., 16, 393-430.

StODART, E. AND PARER, I. 1988. Colonisation of Australia by the Rabbit. CSIRO, Australia.

SWOFFORD, D. L. AND SELANDER, R. B. 1989. BIOSYS-1. $A$ Computer Program for the Analysis of Allelic Variation in Population Genetics and Biochemical Systematics. Release 1.7. University of Illinois, Urbana, ILL.

TAYLOR, J., FREEDMAN, L., OLIVIER, T. J. AND MCCLUSKEY, J. 1977. Morphometric distances between Australian wild rabbit populations. Aust. J. Zool., 25, 721-732.

TGGE HANDBOOK 1993. DIAGEN, GmbH, Germany.

WARTELl, R. M., HOSSEINI, S. H. AND MORAN, C. P. 1990. Detecting base pair substitutions in DNA fragments by temperature-gradient gel electrophoresis. Nucl. Acids Res., 18, 2699-2705.

WEBB, N. J. 1988. Genetic Analysis of Social Structure in the European Wild Rabbit Oryctolagus cuniculus (L.). Ph.D. Thesis, University of East Anglia.

WILSON, A. C., CANN, R. L., CARR, S. M., GEORGE, M., GYLLENSTEN, U. B., HELM-BYCHOWSKI, K. M. ET AL. 1985. Mitochondrial DNA and two perspectives on evolutionary genetics. Biol. J. Linn. Soc., 26, 375-400.

WILSON, G., DEXTER, N., O'BRIEN, P. AND BOMFORD, M. 1992. European wild rabbit (Oryctolagus cuniculus). In: Bureau of Rural Resources (eds) Pest Animals in Australia, pp. 8-13. Kangaroo Press, Australia.

WRIGHT, s. 1951. The genetical structure of populations. Ann. Eugen., 15, 323-354. 